INTERNATIONAL HIGHER EDUCATION, NO. 67, Spring, 2012

Pages 14-16

\title{
Ideas of Student Mobility in Germany
}

\author{
ULRICH TEICHLER
}

Ulrich Teichler is professor at the International Centre for Higher Education Research, at the University of Kassel, Germany. E-mail: mann@incher.uni-kassel.de.

The European Union's decision in 1986, to establish the ERASMUS program for the promotion of temporary student mobility within Europe, was understood as nondur-

able in scope. Moreover, ERASMUS should be discontinued, not only if it did not have a major stimulation effect but also if it was successful. In the latter case, all European countries would take over the funding nationally.

In Germany, public funds for the mobility of students and young researchers traditionally have served two priority areas: support for inwards and outwards mobility of doctoral candidates and support for students from developing countries for degrees of any kind in Germany.

Initially, the ERASMUS program was not well received in Germany. Governments objected it as the European intrusion into national and regional policy domains. The credit system within ERASMUS, starting in 1989, was viewed as incompatible-with varied education and examinations across European countries. According to evaluation studies, German university professors were least inclined to recognize study abroad as equivalent to study at home. 
The situation changed in the mid-1990s. Germany became one of the key drivers for the establishment of a bachelor's and master's degree structure in Europe, to facilitate student mobility. Around 2005, a target was set to have about 20 percent of foreigners, among all students, enrolled in Germany, by 2020.

Available international statistics on foreign students seem to indicate that Germany has hosted, over decades, above-average numbers of students from other countries, in absolute and relative terms. Studying abroad among German students has also seemed above the average in economically advanced countries. As widely accepted, these shares should be above average in the future, and no controversies have emerged hitherto, regarding costs and funding of such objectives.

\section{EXPERIENCES IN THE Bologna Process}

The ministers in charge of higher education in many European countries suggested in 1999, in the Bologna Declaration, to introduce a bachelor's and master's degree structure. This policy was considered as instrumental for both increasing the attractiveness of study in Europe for outside students and facilitating intra-European mobility.

However, as shown in two studies-EURODATA and Mapping Mobility, published by the Academic Cooperation Association in 2006 and 2011-internationally available statistics are in such a deplorable state that the goal achievement can hardly be measured. Most countries measure citizenship, but not mobility for the purpose of study. Yet, available in-depth data suggest that one-quarter of foreign students in Europe have lived in the country beforehand and that one-tenth of the mobile students are not foreign but, rather, returners. Only about half of the temporarily mobile students 
are included in the available international statistics. The international, data-collecting agencies-UNESCO (United Nations Educational, Scientific and Cultural Organization), OECD (Organization for Economic Cooperation and Development) and Eurostat (the statistical office of the European Union)—even recommend excluding short-term mobility. International statistics of doctoral students are unreliable. Recently, many European countries have begun to gather data on genuine student mobility, although not yet a complete picture.

The above named, Mapping Mobility, study presents the following estimates to assess the impact of the Bologna process. The absolute number of students in Europe originating from outside doubled within eight years. Intra-European student mobility might have grown slightly, but it is doubtful whether the Bologna process had speeded up the growth process. Graduate surveys indicate that the proportion of students having spent a study period in another country during their education varies dramatically by country-from about 2 percent to almost 30 percent. In Germany, student mobility has grown in all respects discussed above. The proportion of incoming mobile students from other European countries raised from 3.2 percent in 1999 to 4.5 percent in 2009 and, from outside Europe, from 2.8 percent to 4.4 percent, as well as study abroad, from 2.8 percent to 5.4 percent. More than 15 percent of recent graduates in Germany have spent a period of study in another country.

Concurrent structural and functional changes of intra-European student mobility occurred among various studies. In some countries the readiness to study temporarily in another country seems to have decreased slightly, because it was considered too difficult to spend a meaningful and recognizable period abroad-in these shorter overall 
periods, up to a degree. Additionally, more students study the whole master program abroad. Finally, the difference of international employment and work between formerly mobile and nonmobile students declines over time-possibly as a consequence of internationalization in general and an internationalization at home policy of higher education institutions. Thus, new curricular strategies might be needed to revitalize the value of mobility.

\section{POLICY Responses}

In the second decade of the 21st century, European governments and respective stakeholders continue to advocate a growth of student mobility, without major changes of modalities. However, concern grew about the increasing costs for accommodating inward degree-mobile students-notably those from outside Europe. Some countries introduced or discuss the introduction of moderate tuition fees for students from outside Europe. Some countries suffering from the current international monetary crisis consider many means of reducing public expenditures and might change their attitudes toward foreign students, in this context.

The European Commission recently has published various proposals for the future of education and research. Expenditures for mobility of students and young researchers should grow. ERASMUS should continue to be the flagship of the European Union's educational policy-under the name "ERASMUS for all." Intercontinental financial support in this domain should be increased. Promoting the mobility of doctoral candidates should be part of programs concerned with young researchers. Finally, 
European loans should be provided for students spending for the whole master's program in another European country.

In Germany, increasing public expenditures for education and science are widely accepted as "investment into the future." There is no contested discussion about public good versus private good. Clearly, vocational training in Germany is traditionally largely paid by employers, advanced vocational training by the learners themselves, and study provisions in higher education by public sources-without fundamentalist discussions about costs and benefits.

Similarly, the tradition of development assistance in Germany is not challenged according to which support should be made available for persons, from low-income and middle-income countries, to study or to undertake doctoral research in Germany. There are no major fundamental debates whether this should be understood as charity, economic investment, international crisis prevention, or whatever else. There are no plans, as exist in some non-European countries, to differentiate between first-class national and possibly European students and second-class other students who have to pay high fees. In those domains, no policy changes in Germany are in sight. 